\title{
Passos do diálogo católico-judaico: em documentos católicos desde a Nostra aetate (NA)
}

\author{
Stages of the Catholic-Jewish dialogue: \\ in Catholic documents since Nostra aetate (NA)
}

\section{Maria Teresa de Freitas Cardoso*}

* Pontifícia Universidade Católica do Rio de Janeiro (PUC-Rio), Rio de Janeiro, RJ, Brasil

\section{Resumo}

É importante que cristãos e judeus prossigam na aproximação e no entendimento recíproco, para que se evitem preconceitos, para que sejam fraternos, vivam segundo sua fé e avancem na contribuição que podem dar ao mundo. 0 presente artigo analisa os principais documentos católicos que mais diretamente dizem respeito ao diálogo católico-judaico desde a Nostra Aetate. 0 último texto referido no artigo, sobre dons e vocação irrevogáveis, é de dezembro de 2015. Nas dimensões que um artigo permite, é oferecida uma visão ampla e representativa da reflexão e das orientações católicas, que se deseja levar para aprofundamento na teologia.

Palavras-chave: Diálogo. Diálogo católico-judaico. Nostra aetate.

* MTFC: Doutora em Teologia, e-mail: mtfcardoso@puc-rio.br 


\section{Abstract}

It is important that Christians and Jews continue to grow closer to each other and in mutual understanding, in order to avoid prejudices, to be fraternal, to live according to their faith and advance in the contribution that they can offer to the world. The present article analyses the principal Catholic documents that most directly speak of the Catholic-Jewish dialogue since Nostra aetate (NA). The last text referred to in the article, about irrevocable gifts and vocation is from December of 2015. Within the parameters which an article permits, a sufficiently ample and representative vision of the reflections and of the Catholic orientations is offered, which is needed to lead to a theological deepening.

Keywords: Dialogue. Catholic-jewish dialogue. Nostra Aetate.

\section{Introdução}

É importante que cristãos e judeus prossigam na aproximação e no entendimento recíproco, para que se evitem preconceitos e que sejam fraternos, vivam segundo sua fé e avancem na contribuição que podem dar ao mundo. Isso se alcança pelo respeito, a estima, a descoberta de laços espirituais, o reconhecimento do chamado e dos dons de Deus, o diálogo e a colaboração em tudo aquilo em que ambas as partes creem, desejam e possam servir ao mundo no bem, na justiça, na misericórdia e na paz.

O presente artigo analisa os principais documentos católicos que mais diretamente dizem respeito ao diálogo católico-judaico desde a Nostra Aetate (NA). São documentos do Concílio Vaticano II, da Comissão para as Relações Religiosas com o Judaísmo, da Pontifícia Comissão Bíblica e do papa Francisco. Apresenta-se uma visão ampla e representativa da reflexão e das orientações católicas, que cumpre ter em conta na vida e aprofundar na teologia. 


\section{Alguns aspectos importantes da declaração conciliar Nostra aetate}

A declaração Nostra aetate (NA) é um dos documentos do Concílio Vaticano II a marcar um novo direcionamento na Igreja. Renovou a atitude da Igreja perante as religiões. Originou-se na reflexão sobre as relações com os judeus. Foi esta reflexão que catalisou o conjunto dos outros parágrafos.

A compreensão do cristianismo é teologicamente referida a suas raízes judaicas. O olhar para os judeus é de apreço e de reconhecimento de seu lugar dentro do amor e do desígnio de Deus. A pregação cristã deve estar atenta a isso, para estar adequada ao espírito evangélico, tendo em conta o seu caráter de reconciliação universal. Os católicos são orientados a reconhecer as raízes judaicas do cristianismo e o patrimônio espiritual comum; são chamados a evitar tudo o que levaria a depreciar os judeus; a rejeitar a culpabilização pela morte de Jesus, que infelizmente existiu por tanto tempo; e condenar todo antissemitismo e tudo o que redunda em qualquer discriminação ou preconceito. A NA convoca para o respeito e a estima, e para os diálogos fraternos.

A NA sublinha que no Antigo Testamento (AT) estão os primórdios da Igreja. Lá encontramos a revelação divina, as promessas, o desígnio salvífico. Deve-se ter em conta um grande patrimônio espiritual comum entre cristãos e judeus. A NA traceja as etapas do plano de Deus com Abraão, com Moisés e os Profetas. Por isso, a Igreja só pode se compreender em relação com as suas raízes no AT. Diz a NA:

Pois a Igreja de Cristo reconhece que os primórdios da fé e de sua eleição já se encontram nos Patriarcas, em Moisés e nos Profetas, segundo o mistério salvífico de Deus. Confessa que todos os fiéis cristãos, filhos de Abraão segundo a fé, estavam incluídos no chamamento do mesmo Patriarca e que a salvação da Igreja estava misteriosamente prefigurada no êxodo do povo eleito da terra da escravidão (NA 4).

Na fé cristã não se encontrariam aí dois planos da salvação. A compreensão cristã do Novo Testamento se vincula com o Antigo Testamento. A Palavra de Deus que foi dada na revelação do Primeiro Testamento não é retirada. Como é afirmada na const. dogm. Dei Verbum, a Palavra de Deus 
no AT "conserva um valor perene" (DV, n. 14). Com a leitura do Novo Testamento, podemos encontrar relações de continuidade e descontinuidade, de preparação e de cumprimento. Porém, a leitura do Antigo Testamento pode ser feita também na respectiva tradição judaica com significado e riqueza, com escuta autêntica da Palavra de Deus.

A NA propõe aos católicos o tema da relação dos cristãos com o povo judaico descrito na comparação de uma raiz e do enxerto. A Declaração Conciliar descreve duplamente, como uma boa oliveira e também como os ramos do zambujeiro. Depois alude à unidade que os cristãos creem que Cristo significa ou que nele se estabelece, o que implica uma perspectiva de abertura e de reconciliação.

Por isso não pode a Igreja esquecer que por meio daquele povo, com o qual em sua indizível misericórdia Deus se dignou estabelecer a Antiga Aliança, ela recebeu a Revelação do Antigo Testamento e se alimenta pela raiz de boa oliveira, na qual como ramos de zambujeiro foram enxertados os Povos. Pois crê a Igreja que Cristo, nossa Paz, mediante a cruz, reconciliou os Judeus e os Povos e a ambos unificou em Si mesmo (NA 4).

A mesma Declaração observa que Jesus Cristo vem dos Judeus, e que dos Judeus são as promessas, a adoção, a glória, a aliança, a Lei, o culto. E nessas raízes estão princípios da fé cristã:

Tem a Igreja sempre ante os olhos as palavras do Apóstolo Paulo a respeito de seus consanguíneos, "de quem é a adoção de filhos, a glória, a aliança, a legislação, o culto de Deus e as promessas; de quem são os Patriarcas e de quem descende segundo a carne Cristo" (Rm 9,4-5), filho da Virgem Maria. Lembramos também que do povo judeu nasceram os Apóstolos, fundamentos e colunas da Igreja, como igualmente muitos daqueles primeiros discípulos que anunciaram ao mundo o Evangelho de Cristo (NA 4).

Com isso, temos dons irrevogáveis para o povo judaico. A perspectiva cristã deve reconhecer não somente essas suas origens, mas também a relação que permanece dada de parentesco espiritual com a religião judaica. São conhecidas as palavras de João Paulo II sobre as relações dos cristãos com os judeus: quando esse tema das relações do cristianismo 
com o judaísmo, tão caro à NA, foi comentado por João Paulo II em sua visita à sinagoga de Roma, em 13/04/1986. O Papa João Paulo II afirmou então que a religião judaica é intríseca à nossa fé ou à nossa religião. São laços de parentesco religioso. João Paulo II disse:

A religião judaica não nos é 'extrínseca', mas, de uma certa maneira, é 'intrínseca' à nossa religião. Nós temos para com ela relações que não temos com nenhuma outra religião. Vós sois nossos irmãos prediletos e, de uma certa maneira, se poderia dizer nossos irmãos maiores (Apud KOCH, 2012, p. 26).

Na fé cristã, Jesus é acreditado como Messias. A NA faz a constatação de que muitos Judeus não reconheceram a vinda de Jesus como messias. Isso se deve compreender segundo o contexto judaico. A NA alude à esperança do dia em que todos os povos aclamarão o Senhor, o que para os cristãos se relaciona com Cristo, mas sempre tem significado de esperança escatológica. Esta seria compreendida a seu modo também pelos judeus.

Parece que o coração do mesmo parágrafo sublinha que os Judeus são e permanecem amados por Deus. Pode parecer que a formulação seja imperfeita, mas em todo o caso o texto se reporta às promessas aos patriarcas, e retoma a carta de Paulo aos Romanos, capítulo 9. Deus permanece com eles com os dons da sua promessa, no seu Amor para com Seu povo, e assim na fidelidade a Suas promessas e Seus dons. E todos do seu povo são amados por Deus. É que são o povo primogênito da revelação desse amor. Sinaliza a aliança e o amor de Deus.

A NA incentiva a aproximação e o entendimento de cristãos e judeus na fraternidade, tomando como motivação maior para isso o intercâmbio do patrimônio espiritual comum, para trocar conhecimento e estima, também estudos e diálogos fraternos:

Sendo pois tão grande o patrimônio espiritual comum aos Cristãos e Judeus, este Sacrossanto Concílio quer fomentar e recomendar a ambas as partes mútuo conhecimento e apreço. Poderá ele ser obtido principalmente pelos estudos bíblios e teológicos e ainda por diálogos fraternos (NA 4). 
A NA provoca uma revisão das atitudes, do modo de se fazerem as pregações e da mentalidade de muitos cristãos. Devem ter os judeus em alta estima como amados de Deus. A NA sublinha que os judeus não devem ser culpabilizados pela morte de Cristo, nem considerados "nem como condenados por Deus, nem como amaldiçoados", dado que isso não teria fundamento, e levou a fomentar depreciações e perseguições. Devese corrigir toda inadequação na pregação que leve a distorções e faltem com o verdadeiro espírito do evangelho. Os cristãos deveriam interpretar a morte e ressurreição de Jesus em relação com toda a humanidade, e pela salvação, e reconciliação das pessoas, a vida, a fraternidade, e a paz.

Correspondendo à intenção primeira da NA, encontramos na declaração um não ao antissemitismo. Isso correspondeu a uma intenção que vinha de reflexões e aproximações desde depois da segunda guerra mundial. O cardeal Kurt Koch, pela aproximação dos 50 anos da NA, proferiu uma conferência para "Construir sobre a Nostra aetate" (KOCH, 2012). Koch acentuou o não ao antissemitismo e lembrou uma importante conferência internacional contra o antissemitismo, em agosto de 1947, em Seelisberg, com cerca de 65 pessoas, entre judeus e cristãos de várias denominações, procurando bases para um diálogo. Fazia-se ver, desde então, que era necessário mudar atitudes e dar uma palavra clara contra todo o antissemitismo. Uma das principais intenções da NA foi proferir um não ao antissemitismo.

O não ao antissemitismo é dito na NA com a lamentação de todos os ódios, as perseguições e as manifestações contra os judeus em qualquer tempo ou por qualquer pessoa:

Além disso, a Igreja, que reprova toda a perseguição contra quaisquer homens, lembrada do comum patrimônio com os Judeus, não por motivos políticos, mas impelida pelo santo amor evangélico, lamenta os ódios, as perseguições, as manifestações anti-semíticas, em qualquer tempo e por qualquer pessoa dirigidas contra os Judeus (NA 4).

Vê-se que NA é importante e constitui uma contribuição relevante às relações católico-judaicas; mas deve-se prosseguir, na memória do passado e na construção do futuro. No respeito, na estima, nos diálogos 
e nos estudos. Caberia aprofundar a teologia, a amizade, e buscar mais o mútuo enriquecimento.

Como disse Kurt Koch, trata-se de construir sobre a NA. Edward Kessler, um judeu especialista do diálogo judaico-cristão, apreciou a linguagem da NA como "nova", de "mútuo entendimento e respeito": um documento novo que mudou as relações, trazendo grandes possibilidades, mas, ele adverte, para o sucesso do documento, haveria ainda, muito que trabalhar (KESSLER, 2013, p. 49). Para Bernhard Grümme, em uma conferência na PUCRS, a NA ainda não está totalmente realizada (GRÜMME, 2013, p 26-53). Ela é o início de um diálogo, um diálogo que está em construção. Isso também é falado pelo Dr Alberto Milkewitz, que, aliás, considera como no aprendizado desse diálogo se pode aproveitar das lições da própria tradição judaica. É que Milkewitz tem presente que o método de diálogo e dos debates está presente no Talmud, e na tradição da educação judaica (MILKEWITZ, 2014, p. 91-102). Seria bom todos procurarem contribuir para que se desenvolvesse diálogos, como pede a NA.

\section{Os principais documentos católicos nos rastros da NA}

É sabido que, em ligação com o Secretariado da Unidade dos Cristãos - depois Conselho Pontifício para a Promoção da Unidade dos Cristãos - , foi estabelecida uma Comissão para as Relações Religiosas com o Judaísmo. Essa comissão deu continuidade ao trabalho antes iniciado e veio a produzir alguns documentos para orientação dos católicos em relação aos judeus. Os principais documentos que mencionaremos são quase todos dessa comissão.

a) Orientações e sugestões para a aplicação da declaração Nostra Aetate (n. 4), de $1^{\circ}$ de dezembro de 1974 :

Vem assinado pelo Cardeal Willebrands na qualidade de presidente da Comissão para as Relações Religiosas com os Judeus. O texto é divulgado no site do Vaticano em inglês e em francês. O documento reafirma a estima pelos Judeus. Reafirma a condenação do antissemitismo e das discriminações. Propõe o desenvolvimento dos estudos doutrinais; Também 
propõe que haja mais oração em comum; Sugere desenvolvimento dos diálogos; Dá para os católicos algumas sugestões pastorais importantes; Como procura a aplicação da NA, esta é bastante citada.

Parece-nos importante uma observação acentuada por Edward Kessler: já que o prólogo desse novo documento afirmou que os cristãos precisam aprender a ter melhor conhecimento de como os Judeus se definem a si mesmos, segundo sua própria experiência. Para Kessler, e isso é sublinhado em seu artigo que aqui citamos, a comissão que redigiu o documento e a Igreja Católica ainda hoje ainda não alcançam tudo o que isso significa (KESSLER, 2013, p. 50). Ou seja, E. Kessler chama a atenção de que isso significa continuar a aprofundar a riqueza do judaísmo como uma fé viva, uma tradição viva, e não apenas arqueologicamente como algo do passado. Assim, não pode ser visto apenas como uma referência das origens da Igreja. O Judaísmo permanece uma realidade atual, viva e próxima.

O documento das Orientações e Sugestões de 1974 dedicou uma seção para a importância que a Igreja queria dar ao diálogo com os judeus. Confirmava que "a Declaração NA provê uma oportunidade de abrir ou continuar um diálogo em vista de melhor entendimento mútuo”. E observava que "o diálogo pressupõe que cada lado deseje conhecer o outro e deseje fazer crescer e aprofundar seu conhecimento do outro"; e ainda se reconheciam as "riquezas de cada tradição" (COMMISSION FOR RELIGIOUS RELATIONS WITH THE JEWS, 1974, n.1).

Sobre a liturgia, levava em conta "os laços que existem entre a liturgia Cristã e a liturgia Judaica”. Deveria haver o cuidado nas homilias e nas traduções dos textos litúrgicos, para que não houvesse distorções (n. 2).

O mesmo documento propõe cuidados para a educação cristã, e que esses cuidados tenham em conta que é o mesmo Deus que é adorado e que fala no Antigo e no Novo Testamento; e mostra que, segundo a fé cristã, ambos os Testamentos estão relacionados (n. 3), o que significa que para o cristão um não elimina o outro.

Além disso, propõe a cooperação em uma ação social comum, "uma ação efetiva para o bem do gênero humano". Judeus e cristãos haveriam de, "no espírito dos profetas", buscar juntos a justiça social e a paz (n. 4). 
b) Notas para uma correta apresentação dos judeus e do judaísmo na pregação e na catequese da Igreja católica (24 de junho de 1985):

Estas notas dão continuidade ao que foi proposto anteriormente. Trata-se de um texto que novamente reflete sobre a relação entre o Antigo e o Novo Testamento, e sobre as raízes judaicas da fé cristã; também sobre como a expressão "os judeus" aparece no NT, e fala de novo sobre a liturgia e a pregação. Considera a história das relações entre cristãos e judeus. Como diz o seu título, está especialmente voltado para a pregação e a catequese da Igreja Católica. Para que sejam adequadas. E de novo se faz ver que "o Judaísmo não deve ser tratado apenas como fundamento histórico e arqueológico" para os cristãos (COMMISSION FOR RELIGIOUS RELATIONS WITH THE JEWS, 1985).

A comissão reconhece no documento a singularidade do povo do Antigo Testamento e a universalidade do desígnio de Deus. Reafirma a necessidade de excluir todo preconceito e antissemitismo, ou tudo que possa levar nessa direção. Os católicos são conduzidos a contemplar Jesus mais adequadamente e a entender a perspectiva do Novo Testamento de modo que não haja preconceitos.

c) Nós recordamos: uma reflexão sobre a Shoah, de 16 de março de 1998

Dissemos que a NA lamentou toda perseguição e manifestação antissemita, mas fazia falta retomar isso de modo mais forte e enfático, e explicitar uma reflexão sobre a atitude dos cristãos ao longo dos séculos e a necessidade de um compromisso com um futuro de relações fraternas responsáveis.

De início, esse documento cita João Paulo II, afirmando ser "justo que a Igreja assuma com maior consciência o peso do pecado de seus filhos, recordando todas aquelas circunstâncias em que, no arco da história, eles se afastaram do espírito de Cristo e do seu Evangelho". Com esse documento, se pede "aos nossos irmãos e irmãs da Igreja Católica [...] a todos cristãos que se unam a nós na reflexão sobre a catástrofe que atingiu o povo judaico e sobre o imperativo moral de fazer com que o egoísmo e o ódio nunca venham a crescer a ponto de semear sofrimentos 
e morte". Pede-se também aos judeus para escutarem a reflexão presente no documento.

Faz então, uma reflexão das atitudes e relações dos cristãos para com os judeus ao longo dos séculos, muitas vezes marcadas por preconceitos e depreciações: "a história das relações entre judeus e cristãos é uma história conturbada" e reconhece que houve "sentimentos de antijudaísmo" e "discriminações" (COMISSÃO PARA AS RELAÇÕES RELIGIOSAS COM O JUDAÍSMO, 1998).

O mesmo texto reflete depois sobre o antissemitismo nazista do Shoah e se pergunta sobre as atitudes dos cristãos, questionando se o sentimento antijudaico não influiu. Insiste no dever de guardar a memória da catástrofe, para que não mais aconteçam discriminações nem se repitam os fatos do passado e nem se permita mais qualquer atitude nessa direção.

No final do texto, o documento se volta para a construção de um futuro humano e fraterno, no respeito recíproco, inclusive reforçado pelos laços espirituais:

[...] um novo futuro, no qual já não haja sentimento anti-judaico nos cristãos, nem sentimento anticristão entre os judeus, mas sim um respeito recíproco compartilhado, como convém àqueles que adoram o único Criador e Senhor e têm um comum pai na fé, Abraão (COMISSÃO PARA AS RELAÇÕES RELIGIOSAS COM O JUDAÍSMO, 1998).

Lembre-se aqui que João Paulo II no ano 2000, na liturgia do perdão, formulou uma prece que rememorava as atitudes dos cristãos contra os judeus, como um dos pecados pelos quais pedir perdão, expressando juntamente que isso não se repita mais.

d) O povo judeu e as suas Sagradas Escrituras na Bíblia cristã, uma obra de caráter exegético e teológico, emitido em 2001 pela Pontifícia Comissão Bíblica:

Edward Kessler observa como é positivo que viesse um texto importante de uma outra autoria, para além da Comissão específica das relações com os judeus, porque significa que a solicitude pela temática não 
é exclusiva da comissão para as relações com os judeus, mas pertence à Igreja como um todo (KESSLER, 2003, p.49).

Este novo documento, lançado em 2001, é bastante amplo e abrangente. A primeira parte dele é, em geral, sobre o povo judeu e as suas Sagradas Escrituras na Bíblia cristã. A segunda parte aprofunda temas fundamentais das Escrituras do povo judeu e a acolhida desses temas no contexto da fé em Cristo. A terceira parte trata da perspectiva do NT.

Na perspectiva cristã, a obra apresenta aspectos de continuidade, de descontinuidade e de progressão entre AT e NT, mas pode ajudar os cristãos a compreender o lugar judaico na origem da tradição cristã e as relações temáticas entre ambos os testamentos, e ainda, ajudar a compreender a linguagem do NT e a prevenir de uma leitura errônea que diminuísse a estima pelos judeus. No conjunto, o livro aprofunda as Escrituras e faz ver muito de parentesco espiritual entre judeus e cristãos. É uma obra que pode e pretende ajudar os católicos a verem a Bíblia percebendo mais a Sagrada Escritura judaica e a respeitarem e apreciarem mais a leitura judaica e a cristã, nas respectivas tradições, bem como os laços entre elas.

e) Os dons e o chamado de Deus são irrevogáveis, declaração por ocasião dos 50 anos de NA, da Comissão para as relações religiosas com os Judeus:

Dado que é o mais recente desses documentos, de importância simbólica e histórica no contexto atual, reservamos ao mesmo a última seção deste artigo (mais adiante).

\section{O diálogo católico-judaico em Evangelii gaudium e Misericordiae vultus}

A exortação Evangelii gaudium (EG) do Papa Francisco, propõe aos católicos uma renovação no espírito do evangelho, com a alegria do evangelho, que leva os fiéis a uma saída ao encontro da pessoa, e estes vão impelidos pelo dom do amor de Deus que se manifestou em Jesus Cristo e comunicou o Seu Espírito. Nesse contexto se propõe uma evangelização em nosso tempo, uma evangelização cujo cerne é testemunhar e servir no mesmo amor de Deus. 
O capítulo 4 trata da dimensão social da evangelização, que vai em busca, sobretudo, de servir as pessoas em vista dos bens do Reino, e busca um caminho de harmonia, colaboração e paz com todas as pessoas, e de auxílio principalmente aos mais frágeis. Na busca do bem, atravessa vários círculos de diálogos. Nos diálogos não se trata impor as convicções ou a fé, mas sim, dar o melhor de si e de se buscar a harmonia e a paz. Por isso, também de se fazer com que os interlocutores estejam em respeito e colaboração, como as faces ou os pontos de um poliedro podem se relacionar e concorrer para o bem e a harmonia do conjunto.

O papa fala em vários círculos de diálogo dos fiéis na sociedade, entre fé e ciência, ou no contexto ecumênico e inter-religioso, ou o diálogo com os que não creem, mas buscam a verdade, a beleza, o bem. Parágrafos especiais se dedicam ao âmbito das relações e do diálogo dos fiéis católicos com os Judeus.

Todo o trecho da EG que trata diretamente da relação com os judeus (parágrafos 247-249) parece prosseguir o espírito da NA com questões de interesse. É nesse trecho que o papa então propõe com simplicidade e clareza, o diálogo e a amizade.

Reencontramos a afirmação de que o povo judeu é um povo cuja Aliança com Deus nunca foi revogada e essa doutrina tem base no próprio Novo Testamento.

Um olhar muito especial é dirigido ao povo judeu cuja Aliança com Deus nunca foi revogada porque os 'dons e o chamamento de Deus são irrevogáveis' (Rm 11, 29). A Igreja, que partilha com o Judaísmo uma parte importante das Escrituras Sagradas, considera o povo da Aliança e a sua fé uma raiz sagrada da própria identidade cristã (cf. Rm 11, 16-18) (EG 247).

Daí o olhar especial que o Povo da Aliança nos solicita, pois compartilhamos também com este, grande parte das Sagradas Escrituras. E, como disse João Paulo II, que já citamos, o papa Francisco também explicita que a religião judaica não fica extrínseca à nossa. Ainda, outro ponto é que não é preciso a missão para que se convertam, pois os Judeus creem já no verdadeiro Deus que atua na história e com eles acolhemos a Palavra revelada. Aliás, volta a afirmação de que a fé cristã tem raízes judaicas. Diz o Papa Francisco: 
Como cristãos, não podemos considerar o Judaísmo uma religião alheia, nem incluímos os judeus entre os que são chamados a deixar os ídolos para se converter ao verdadeiro Deus (cf. 1Ts 1,9). Juntamente com eles, acreditamos no único Deus que atua na história e acolhemos, com eles a Palavra revelada comum" (EG 247).

A esta altura do documento, papa Francisco propõe o diálogo e a amizade de cristãos com os Judeus: "O diálogo e a amizade com os filhos de Israel fazem parte da vida dos discípulos de Jesus" (EG 248). O passo seguinte, no mesmo parágrafo 248 , é uma expressão de afeto. Com esse afeto principalmente, o papa faz lamentar todas as terríveis perseguições, considerando, particularmente aquelas que envolvem ou envolveram cristãos:

O afeto que se desenvolveu leva-nos a lamentar, sincera e amargamente, as terríveis perseguições de que foram e são objeto, particularmente aquelas que envolvem ou envolveram cristãos (EG 248).

Orienta-se para o reconhecimento do valor e da riqueza e do dinamismo da tradição judaica, como foi expresso nos documentos que sucederam a NA, posto que Deus continua operando riquezas espirituais em seu interior:

Deus continua a operar no povo da Primeira Aliança e faz nascer tesouros de sabedoria que brotam do seu encontro com a Palavra divina. Por isso, a Igreja também se enriquece quando recolhe os valores do Judaísmo.

O papa tem presente as diversidades e, embora a Igreja tenha convicções que o Judaísmo não professa e tenha um mandato evangelizador universal (que é um tema levantado no recente documento da Comissão para as Relações Religiosas com o Judaísmo), haveria que considerar as possibilidades de complementaridade no aprofundamento da Palavra, e de compartilhamento de convicções éticas e colaboração para a justiça e a paz: 
Embora algumas convicções cristãs sejam inaceitáveis para o Judaísmo e a Igreja não possa deixar de anunciar Jesus como Senhor e Messias, há uma rica complementaridade que nos permite ler juntos os textos da Bíblia hebraica e ajudar-nos mutuamente a desentranhar as riquezas da Palavra, bem como compartilhar muitas convicções éticas e a preocupação comum pela justiça e o desenvolvimento dos povos.

Consideramos que os temas do bem, da justiça e da paz encontram na misericórdia não só suas expressões correlatas, mas também seu prosseguimento. Com efeito, o tema da misericórdia suscita desdobramentos para o diálogo. Na Bula Misericordiae vultus, de proclamação do Jubileu extraordinário da Misericórdia, o papa Francisco recorreu ao patrimônio comum espiritual judaico e cristão, valorizou a tradição judaica, inclusive citando diversos textos bíblicos de ambos os Testamentos, e depois convidou a um ainda mais amplo diálogo inter-religioso sobre o tema da misericórdia (FRANCISCO, 2015, n. 23).

Seria sempre útil sublinhar que o tema da misericórdia é comum aos judeus e aos cristãos e permitiria um desenvolvimento do diálogo dos cristãos com os judeus em um dado fundamental da sua fé. Com seu dado comum e suas respectivas tradições, judeus e cristãos podem prestar ao mundo um testemunho valioso: que Deus é Deus de misericórdia; seu povo é arauto da Sua misericórdia e deve testemunhar a sua misericórdia sendo também sinal dela, assim como são portadores e arautos de sua bênção. Abraão foi chamado a ser bênção para todas as nações. Moisés conheceu Deus como Deus de misericórdia. Os profetas anunciam a misericórdia de Deus, que acolhe e ensina seu povo. Por sua vez, Jesus proclamou um evangelho de misericórdia e conclamou a sermos misericordiosos como o Pai.

\section{0 recente documento Os dons e o chamado de Deus são irrevogáveis}

O documento da Comissão para as Relações Religiosas com o Judaísmo mais significativo dos tempos recentes é o texto "Os dons e o chamado de Deus são irrevogáveis" (Rm 11, 9): uma reflexão sobre questões teológicas em torno às relações entre católicos e judeus no $50^{\circ}$ aniversário da "Nostra Aetate" (n. 4). O texto é datado de 10 de dezembro de 2015. 
Rememora os 50 anos da NA repassando resultados e oferecendo estímulos. Pretende refletir "sobre temas teológicos atuais, a partir do Concílio Vaticano II [...], com vistas a enriquecer e intensificar a dimensão teológica do diálogo Judaico-Católico" (COMISIÓN PARA LAS RELACIONES RELIGIOSAS COM EL JUDAÍSMO, 2015, Preâmbulo).

A comissão repassa resultados anteriores. Primeiro, sobre a NA; depois, sobre os outros documentos, relembrados em linhas gerais. Acentua a importância de relações pessoais, pois "por mais importância de que se revistam, os textos e documentos não podem substituir os encontros pessoais e o diálogo face a face" (n. 8). São mencionados o diálogo com o Comitê Judaico Internacional para Consultas Inter-religiosas, o diálogo do Comitê de Ligação Internacional Católico-Judaico e o diálogo com o Grão Rabinado de Israel. E com grupos diversos. Em particular, o empenho dos últimos papas. Consideram-se as seguintes questões:

a) O estatuto teológico especial do diálogo Judaico-Católico (n. 14-20): não é propriamente um diálogo inter-religioso, no sentido de religiões separadas. Existem laços, desde as raízes judaicas do cristianismo e a continuidade de uma relação com os Judeus. João Paulo II chamou os Judeus de "irmãos maiores"; e o Papa Bento XVI, de "pais na fé". Jesus foi um Judeu, inserido na tradição judaica, inclusive na sua proclamação da vinda do Reino de Deus. Não se compreende Sua mensagem sem o horizonte judaico. Os primeiros cristãos eram judeus, que se reuniam na sinagoga. As Escrituras sagradas dos Judeus integram as Escrituras do Cristianismo, como Palavra de Deus, revelação e história da salvação. Na perspectiva cristã se professa um cumprimento das promessas. O conflito de Jesus com as autoridades judaicas de seu tempo foi pela sua pretensão de estar atuando com autoridade divina. Existe uma divergência no contexto da fé e o judaísmo também se desenvolveu com caminho próprio posteriormente, mas permanece uma relação. Houve separação, hostilidades, difamação e conflitos cruéis. A teoria da substituição, que se desenvolveu principalmente na Idade Média, e que vê a Igreja de Cristo como novo Israel e novo Povo eleito por Deus no lugar dos Judeus, carece de fundamento: como 
mostra a NA, permanece o amor de Deus para com os Judeus. A carta aos Romanos 9 é fundamental para compreender a condição dos Judeus. A carta aos Hebreus pressupõe a permanente validade das promessas da antiga aliança, a cumprir-se de modo definitivo em Cristo. A fé do Antigo Testamento é fundamento da fé cristã. As relações dos cristãos com os judeus, e do diálogo, têm um estatuto especial.

b) A revelação na história como "Palavra de Deus" no Judaísmo e no Cristianismo (n. 21-26): "no Antigo Testamento encontramos o programa do plano salvífico de Deus traçado para seu Povo” (n. 21). É eleição com Abraão, revelação gradativa, mediante os profetas. O povo tomou consciência de sua vocação com a libertação e aliança do Sinai. Sempre houve no povo um "resto" preservado por meio do qual Deus reúne e reconduz a humanidade. O povo de Israel como povo de Deus não deixou de existir, mesmo se a Igreja é chamada de Novo Povo de Deus. Ela representa cumprimento das promessas e não substituição. Deus se revelou por sua Palavra. Os Judeus encontram essa Palavra e sua unidade na Torá, que é "instrução para uma vida feliz em relação correta com Deus", para se ter "vida em plenitude". Os cristãos têm sua unidade em Cristo. Ambas as tradições são caminhos do povo de Deus apropriar-se das Sagradas Escrituras. As Escrituras, que os cristãos chamam de AT "se abre a ambos os caminhos". Os cristãos têm Jesus como novo Moisés e a Torá vivente de Deus, ou como intérprete da Torá. Torá e Cristo representam o caminho da salvação.

c) A relação entre Antigo e Novo Testamento, Antiga e Nova Aliança (n. 27-34): Afirma-se que "a aliança que Deus dispôs com Israel é irrevogável”, dada "a permanente fidelidade eletiva de Deus”. A Nova Aliança não as revoga. Dá-lhes confirmação e cumprimento, como ponto culminante. As raízes do cristianismo estão no AT, e ele vive dessas raízes, em permanente relação, ao mesmo tempo tendo um fundamento em Jesus Cristo, professando-o como Messias e Filho de Deus, que se comunica a nós pelo Espírito Santo. A heresia de 
Marcião foi recusada, pois se reconhece a continuidade e unidade de ambos os Testamentos, testemunhando a fé em um e único Deus, autor de ambos. A exegese cristológica não autoriza a substituição, mas vê no antigo a profecia do Novo e o Novo como a exposição do Antigo. O Judaísmo rabínico após a destruição do Segundo Templo em 70 desenvolveu sua própria exegese, em parelelo. Os dois caminhos de interpretação se afastaram entre si. No entanto, é possível ler, segundo as próprias tradições, e poderia haver uma ajuda mútua para aprofundar as riquezas da Palavra de Deus. Existe uma única história da aliança de Deus com a humanidade. Assim, para os cristãos, "a Nova Aliança não representa nem a anulação nem a substituição, mas a plenitude das promessas da Antiga Aliança”. A Aliança anterior é irrevogável e constitutiva, sem a qual os cristãos não encontrariam seu lugar na história da salvação. Para eles, a nova aliança confere a universalidade pretendida no chamado de Abraão, de modo que haveria uma interdependência.

d) A universalidade da salvação em Jesus Cristo e a Aliança irrevogável de Deus com Israel (n. 35-39): Existe apenas um caminho de salvação: "Posto que Deus jamais revogou sua aliança com o Povo de Israel, não pode haver caminhos ou aproximações diferentes para a salvação de Deus”. Pertence à fé cristã a profissão de que Deus quer a salvação de todos e que Jesus Cristo é mediação única e universal da salvação. Que Ele cumpre as promessas. As nações orarão ao Deus de Israel como único Deus. No desígnio da salvação Israel tem uma missão única, como "filho primogênito" (Êx 4, 22). Na carta aos Romanos, São Paulo afirma que a salvação vem dos judeus. É o povo da antiga aliança; e as promessas e a aliança de Deus são irrevogáveis. Por isso, "que os Judeus são partícipes da salvação de Deus é teologicamente inquestionável” (n. 36). Para os cristãos, esse único desígnio universal da salvação de Deus culmina em Jesus como Salvador. A comissão sugere que a teologia aprofunde a reflexão sobre os modos da salvação. No nosso entender, a teologia deve procurar descortinar e aprofundar o caminho da salvação universal 
querida por Deus, como dom da gratuidade do amor de Deus, tanto para cristãos como para não cristãos.

e) O mandato da Igreja de evangelizar visto em relação com o Judaísmo (n. 40-43): O tema é sensível para os Judeus, pois vem implicada a existência do Povo Judaico. O tema é importante para os cristãos, pela missão universal da Igreja. As especiais relações com os Judeus incidem nesse campo: "Na prática isso significa que a Igreja Católica não atua nem sustenta nenhuma missão institucional específica dirigida aos Judeus" (n. 40), embora os cristãos devam dar testemunho de sua fé, humilde e cuidadosamente (n. 40). A missão dos cristãos se faz na vida pessoal, na proclamação e no serviço aos necessitados. A Igreja da Nova Aliança é formada de Judeus e Gentios. Nos passos da LG 16, o documento vê a todos os povos, que todavia não receberam o Evangelho, como orientados para o Povo de Deus da Nova Aliança. Primeiramente o Povo de Deus das promessas, amado, com dons irrevogáveis.

f) As metas do diálogo com o Judaísmo (n. 44-49): O documento se conclui com as seguintes metas: "aprofundar no conhecimento recíproco entre Judeus e Cristãos"; "compromisso conjunto em escala mundial em favor da justiça, da paz, da conservação da criação e da reconciliação"; "luta conjunta contra todas as manifestações de discriminação racial antijudaica e todas as formas de antissemitismo"; colaboração na "caridade social" e, como filhos de Abraão, responder à vocação de ser bênção para o mundo.

\section{Considerações finais}

A Declaração Nostra aetate (NA) é um marco fundamental para a Igreja Católica em relação com outras religiões, e especialmente, em relação com o Judaísmo. Desde a NA foi grande o empenho, por parte de cristãos e de judeus, de desenvolver um diálogo. O diálogo está em construção. Tem um estatuto especial entre os diálogos inter-religiosos, dado o particular parentesco espiritual. 
Da parte católica, alguns documentos são significativos para: consolidar relações de respeito e estima; reconhecer as raízes judaicas do cristianismo e os laços de parentesco espiritual, particularmente na Escritura e na liturgia; apreciar os valores das respectivas tradições; desenvolver a colaboração no bem e na prática da justiça e da paz; ver os Judeus não somente, arqueologicamente, como origem da fé cristã, mas como tradição viva. As respectivas leituras bíblicas são possíveis e podem contribuir para aprofundar as riquezas da Palavra de Deus. A evangelização cristã deve ter cuidado especial de respeitar a fé e a tradição judaica e ver os judeus como povo da aliança de Deus, com lugar no desígnio salvífico. É necessário reconhecer que o chamado e os dons de Deus são irrevogáveis.

\section{Referências}

COMISIÓN PARA LAS RELACIONES RELIGIOSAS COM EL JUDAÍSMO. Los dones y la llamada de Dios son irrevocables (Rm 11, 29): Una reflexión sobre cuestiones teológicas en torno a las relaciones entre Católicos y Judíos en el $50^{\circ}$ aniversario de "Nostra Aetate" N 4. Disponível em: <http://www.vatican.va/ roman_curia/pontifical_councils/chrstuni/relations-jews-docs/rc_pc_chrstuni_ doc_20151210_ebraismo-nostra-aetate_sp.html>. Acesso em: 10 jan. 2016.

COMISSÃO PARA AS RELAÇÕES RELIGIOSAS COM O JUDAÍSMO. Nós recordamos: Uma reflexão sobre o Shoah. (16 mar 1998) Disponível em: <http:// www.vatican.va/roman_curia/pontifical_councils/chrstuni/documents/rc_pc_ chrstuni_doc_16031998_shoah_po.html>. Acesso em: 22 abr. 2015

COMMISSION FOR RELIGIOUS RELATIONS WITH THE JEWS. Guidelines and suggestions for implementing the concilicar declaration "Nostra Aetate".n. 4, $01 \mathrm{dez}$ 1974. Disponível em: <http://www.vatican.va/roman_curia/pontifical_ councils/chrstuni/relations-jews-docs/rc_pc_chrstuni_doc_19741201_nostraaetate_en.html>. Acesso em: 22 abr. 2015. 
COMMISSION FOR RELIGIOUS RELATIONS WITH THE JEWS. Notes on the correct way to present the Jews and Judaism in preaching and catechesis in the Roman Catholic Church, 24 jun 1985. Disponível em: <http://www.vatican.va/ roman_curia/pontifical_councils/chrstuni/relations-jews-docs/rc_pc_chrstuni_ doc_19820306_jews-judaism_en.html>. Acesso em: 22 abr. 2015

CONCÍLIO VATICANO II. Declaração Nostra Aetate. In: Compêndio do Vaticano II. Constituições. Decretos. Declarações. 21 ed. Petrópolis: Vozes, 1991.

CONCÍLIO VATICANO II. Constituição dogmática Dei Verbum. In: Compêndio do Vaticano II. Constituições. Decretos. Declarações. 21 ed. Petrópolis: Vozes, 1991.

FRANCISCO. Exortação Apostólica Evangelii Gaudium - A alegria do Evangelho: sobre o anúncio do Evangelho no mundo atual. São Paulo: Paulus / Loyola, 2013.

FRANCISCO. Misericordiae Vultus. Bula de proclamação do Jubileu Extraordinário da misericórdia. São Paulo: Paulinas, 2015.

GRÜMME, B. Ainda não realizada: Nostra Aetate e suas perspectivas para uma visão cristã do Judaísmo. Teocomunicação, v. 43, n. 1, p. 26-53, 2013.

KESSLER, E. “I am Joseph, your brother": a jewish perspective on christianjewish relations since Nostra Aetate n. 4. Theological Studies, v. 74, p. 48-72, 2013.

KOCH, K. Construire sur Nostra Aetate: 50 ans de dialogue entre juifs et chrétiens". Service d'Information. v. 139 (I-II), p. 25-33, 2012.

MILKEWITZ, A. O diálogo nas tradições judaica e cristã: A Igreja Católica e os Judeus, um diálogo em construção. Revista Eletrônica Espaço Teológico v. 8, n. 13, p. 91-102, 2014.

PONTIFÍCIA COMISSÃO BÍBLICA. O Povo Judeu e as suas Sagradas Escrituras na Bíblia Cristã. São Paulo: Paulinas, 2002.

Recebido: 10/01/2016

Received: 01/10/2016

Aprovado: 14/02/ 2016

Approved: 02/14/ 2016 